\title{
Inheritance Pattern of Quantitative Characters in Brassica juncea
}

\author{
Ranjana*, Ranjeet Singh, K. Kumar and D.K. Sharma \\ Department of Genetics and Plant Breeding, \\ Narendra deva University of Agriculture and technology, Faizabad, India
}

*Corresponding author

\section{A B S T R A C T}

\begin{tabular}{|l|}
\hline Ke y w o r d s \\
$\begin{array}{l}\text { Brassica juncea; } \\
\text { Variation, Additive, } \\
\text { Dominance, Diallel } \\
\text { cross }\end{array}$ \\
\hline Article Info \\
\hline $\begin{array}{l}\text { Accepted: } \\
\text { 06 June } 2018 \\
\text { Available Online: } \\
\text { 10 July } 2018\end{array}$ \\
\hline
\end{tabular}

\section{Introduction}

Oilseed production assumes great importance in India because of gap in demand and supply of edible oils, which forced our country to import vegetable oils of millions of rupees, causing a heavy drain of the foreign exchange in past years. India is one of the important rapeseed- mustard growing country in the world occupying second position in area and third position in production after China, Canada (Anonymous, 2008). Total production of rapeseed-mustard in India during 1978 was $1.6 \mathrm{~m}$ tonnes in an area of $3.54 \mathrm{~m}$ hectares (Anonymous, 2008), which increased in 200910 by $6.40 \mathrm{~m}$ tonnes in an area of $6.45 \mathrm{~m}$ hectares with the productivity of about 990 $\mathrm{kgha}^{-1}$. Oilseeds account for nearly $14 \%$ of gross national product and $7 \%$ of the value of all agricultural products. These oilseeds are being raised mostly under rainfed conditions and are very important for the livelihood security of small and marginal farmers in the arid and semi-arid eco-regions of the country.

Keeping in view, the magnitude of edible oil shortage, development and improvement work needs serious attention. Improvement through breeding can be made successful by knowing the genetic behavior and creating genetic variability in Brassica seed. In the perspective of afore explained situation the present study 
was planned to study the inheritance pattern of quantitative characters which influence the seed yield and oil content in Brassica juncea.

\section{Materials and Methods}

The present study was carried out at research field of the Department of Genetics and Plant Breeding, Narenda Deva University of Agriculture and Technology, Faizabad. The experiment comprised of ten genotypes of $B$. juncea viz., Varuna, RKM 3, RK-08-02, Maya, SKM 0526, HUJM-05-03, RGN-229, RH-0512, LET-3, Purple mutant and Kranti (check), which were sown in field and crossed in a diallel fashion excluding reciprocals during 2008-09. Crosses and parents were sown in Randomized Block Design with three replications in 2009-10 with row to row and plant to plant spacing of 30 and $10 \mathrm{~cm}$, respectively. Normal agronomic practices were followed for raising the crop. At maturity, 10 guarded plants were randomly selected in each replication for recording observations in each cross.

\section{Statistical procedure}

Before subjecting the data to diallel analysis technique, data were subjected to analysis of variance (Panse and Sukhatme, 1967) to see the significance of genotypic differences among $\mathrm{F}_{1}$ hybrids and their parents. To determine the adequacy of additive dominance model, and validity of some of the assumptions underlying the model, preliminary analysis of the data was done following Numerical (Griffing, 1956 b) and Graphical analysis (Hayman, 1954a,b and Jinks, 1954). From the data set, variance of components of each array ( $\mathrm{Vr}$ ), the covariance of the parents with their offsprings in each array (Wr), and the variance of parental means $\left(\mathrm{V}_{0} \mathrm{~L}_{0}=\mathrm{Vp}\right)$ was calculated. Other statistics were worked out including the computation of the means of array variance $\left(\mathrm{V}_{1} \mathrm{~L}_{1}\right)$, the variance of means of arrays $\left(\mathrm{V}_{0} \mathrm{~L}_{1}\right)$, and the mean of array covariance $\left(\mathrm{W}_{0} \mathrm{~L}_{0}\right)$. All these statistics were used to calculate the genetic components of variation for different characters. The components under the simple additive-dominance model are: D (component of variation due to additive effects of the genes); $\mathrm{H}_{1}$ and $\mathrm{H}_{2}$ (component of variation due to dominance effects of the genes); $\mathrm{H}$ (direction of dominance effects towards positive or negative); $\mathrm{F}$ (estimates of the relative frequency of dominant to recessive alleles in the parents, and variation in dominance over the loci). These estimates were obtained by removing the environmental component; E which was halved in the present study, since reciprocal $\mathrm{F}_{1}$ families were assumed to have identical expectations and therefore, was averaged (Mather and Jinks, 1982). Estimates of narrow sense heritability for number of seeds per siliqua, 1000-seed weight, seed yield per plant and oil content were calculated from the genetic components according to the formula given by Crumpacker and Allard, (1962)

\section{Results and Discussion}

The analysis of variance of means of 10 parents and $45 \mathrm{~F}_{1}$ families revealed highly significant differences $(\mathrm{P}<0.01)$ for number of seeds per siliqua, 1000-seed weight, seed yield per plant and oil content (Table 1). These significant differences validated the use of simple additive dominance model for genetic analysis of the diallel data. To test the suitability of the present data for genetic analysis and validity of the major assumptions underlying the genetic model, two scaling tests i.e. joint regression analysis and analysis of variance of $(\mathrm{Wr}+\mathrm{Vr})$ and $(\mathrm{Wr}-\mathrm{Vr})$ were carried out. Regression coefficient (b) is expected to be differed significantly from zero but not from unity if all the assumptions are met (Hayman, 1954a, b; Jinks, 1954). The unite slope of regression line for number of 
seeds per siliqua $(b=1.32+0.36$, Fig. 1$)$, 1000-seed weight $(b=1.77+0.41$, Fig. 2), seed yield per plant $(b=1.42+0.19$, Fig. 3$)$ and oil content $(b=2.47+0.29$, Fig. 4) and significance of differences of $(\mathrm{Wr}+\mathrm{Vr})$ and (Wr-Vr) of the four characters (given in Fig. 1-4) revealed that additive-dominance model was fully adequate for the expression of number of seeds per siliqua, 1000-seed weight and seed yield per plant. The scaling test provided further evidence of the presence of non-allelic interaction in the inheritance of these characters except for oil content. The estimates of genetic variation for number of seeds per siliqua, 1000 seed weight, seed yield per plant and oil content are given in Table 2. Although $\mathrm{D}, \mathrm{H}_{1}$ and $\mathrm{H}_{2}$ components were positive and significant for all the characters.

Seed yield per plant and oil content showed greater magnitude of $\mathrm{H}_{1}$ and $\mathrm{H}_{2}$ than that of $\mathrm{D}$ revealed the importance of non-additive gene effects. As the magnitude of $\mathrm{H}_{1}$ is greater than $\mathrm{H}_{2}$ therefore, distribution of negative and positive alleles were unequally distributed in the parents and further proof of this unequal distribution of alleles over loci by the ratio of $\mathrm{H}_{2} / 4 \mathrm{H}_{1}$, which is lesser than its maximum value 0.25 (Table 2). Positive value of $F$ of these four characters suggested that dominant alleles were more abundant than the recessive alleles in the parents, and this claim was supported by the ratio of $\left(4 \mathrm{DH}_{1}\right) 0.5+\mathrm{F} /$ $\left(4 \mathrm{DH}_{1}\right) 0.5-\mathrm{F}$ which is more than one for all the characters. The negative value of $\mathrm{H}(-0.16)$ suggested, the direction of dominance towards the lesser number of seeds/ siliqua, while Positive value of $\mathrm{H}$ for rest of the characters indicated the trend of dominance towards the parent (Table 2). The ratio of $\mathrm{H}_{1} / \mathrm{D}$ is more than 1, revealed the presence of over dominance in the genes. Narrow sense heritability for number of seeds per siliqua (23), 1000-seed weight (23), seed yield per plant (24) and oil content (16) is medium, which suggested the role of non-additive genes in the inheritance of above traits. The study of $\mathrm{Wr} / \mathrm{Vr}$ graph in Figure 1 shows that RH-0512 had maximum number of dominant genes and LET-3 being away from origin carried maximum number of recessive genes for number of seeds per siliqua. In Figure 2, RH-0512 had maximum number of dominant genes and RK-08-02 being away from origin carried maximum number of recessive genes for 1000-seed weight and Figure 3 shows that RK-08-02 had maximum number of dominant genes and Purple mutant being away from origin carried maximum number of recessive genes for seed yield per plant. While for oil content the ' $b$ ' value was significant from unity indicating the presence of non-allelic interaction or the failure of assumptions by graphical method and not by numerical method as $\mathrm{t}^{2}$ value was non-significant. Under such situation also the values of genetical components can be calculated, but not much reliable. In Figure 4 parent RKM-3 had maximum number of dominant genes and LET-3 being away from origin had maximum number of recessive genes for oil content.

In order to bring improvement, through selection, the availability of genetically based variation is essential in any breeding population. In the present study, the statistical analysis of the data showed that the genotypes differed significantly from each other for these four quantitative characters (Table 1). For rapid genetic improvement, thorough understanding about the pattern of inheritance of variation in different plant characteristics is an essential pre-requisite for plant breeder. The information on different genetic components of variation, i.e. additive, nonadditive, epistasis and linkage may be useful to develop an appropriate selection protocol while handling the segregating generations. Diallel cross technique is commonly used by the breeders to collect such genetic information for the plant material at hand. 
Table.1 Mean squares of some quantitative traits in Brassica juncea able II. Components of variation in B. junsia

\begin{tabular}{|c|c|c|c|c|}
\hline \multirow{3}{*}{ Characters } & & \multicolumn{3}{|c|}{ Source of variation } \\
\hline & & Replication & Treatments & Error \\
\hline & d.f. & 2 & 55 & 110 \\
\hline No. of seeds per siliqua & & $9.54^{\mathrm{ns}}$ & $11.19 * *$ & 1.26 \\
\hline 1000-seed weight $(\mathrm{g})$ & & $0.22^{\mathrm{ns}}$ & $0.44 * *$ & 0.26 \\
\hline Seed yield per plant (g) & & $0.72^{\mathrm{ns}}$ & $53.66 * *$ & 2.43 \\
\hline Oil content (\%) & & $14.68^{\mathrm{ns}}$ & $2.20 * *$ & 0.22 \\
\hline
\end{tabular}

* = Significant, $* *$ = Highly Significant, NS = Non Significant

Table. 2 Components of variation in $B$. junsia

\begin{tabular}{|c|c|c|c|c|}
\hline Source & Seeds per siliqua & \multicolumn{1}{l|}{$\begin{array}{l}\text { 1000 seed } \\
\text { weight }\end{array}$} & $\begin{array}{l}\text { Seed yield per } \\
\text { plant }\end{array}$ & Oil content \\
\hline$\hat{\mathrm{D}}$ & $5.01 \pm 1.19$ & $0.21 \pm 0.06$ & $36.6 \pm 5.66$ & $0.84 \pm 0.19$ \\
\hline$\hat{\mathrm{F}}$ & $6.41 \pm 2.74$ & $0.19 \mathrm{v} 0.14$ & $46.1 \mathrm{v} 13.06$ & $1.02 \pm 0.44$ \\
\hline$\hat{\mathrm{H}}_{1}$ & $14.34 \pm 2.53$ & $0.91 \pm 0.13$ & $67.8 \pm 12.05$ & $2.76 \pm 0.41$ \\
\hline$\hat{\mathrm{H}}_{2}$ & $10.98 \pm 2.15$ & $0.80 \pm 0.11$ & $50.8 \pm 10.24$ & $2.38 \pm 0.35$ \\
\hline $\mathbf{H}$ & $-0.16 \pm 1.44$ & $0.25 \mathrm{v} 0.08$ & $41.55 \pm 6.85$ & $0.05 \pm 0.23$ \\
\hline$\hat{\mathrm{E}}$ & $0.47 \pm 0.36$ & $0.01 \pm 0.02$ & $0.81 \pm 1.71$ & $0.16 \pm 0.06$ \\
\hline$\left(\mathrm{H}_{1} / \mathrm{D}\right)^{0.5}$ & 1.69 & 2.08 & 1.36 & 1.81 \\
\hline$\left(\mathrm{H}_{2} / 4 \mathrm{H}_{1}\right)$ & 0.19 & 0.22 & 0.19 & 0.22 \\
\hline$\left(\mathrm{KD}_{\mathbf{H}} / \mathrm{KR}\right)$ & 2.22 & 1.54 & 2.72 & 2 \\
\hline $\mathbf{h 2}$ & 23 & 23 & 24 & 16 \\
\hline
\end{tabular}


Fig.1 Vr/Wr graph for seeds/siliqua

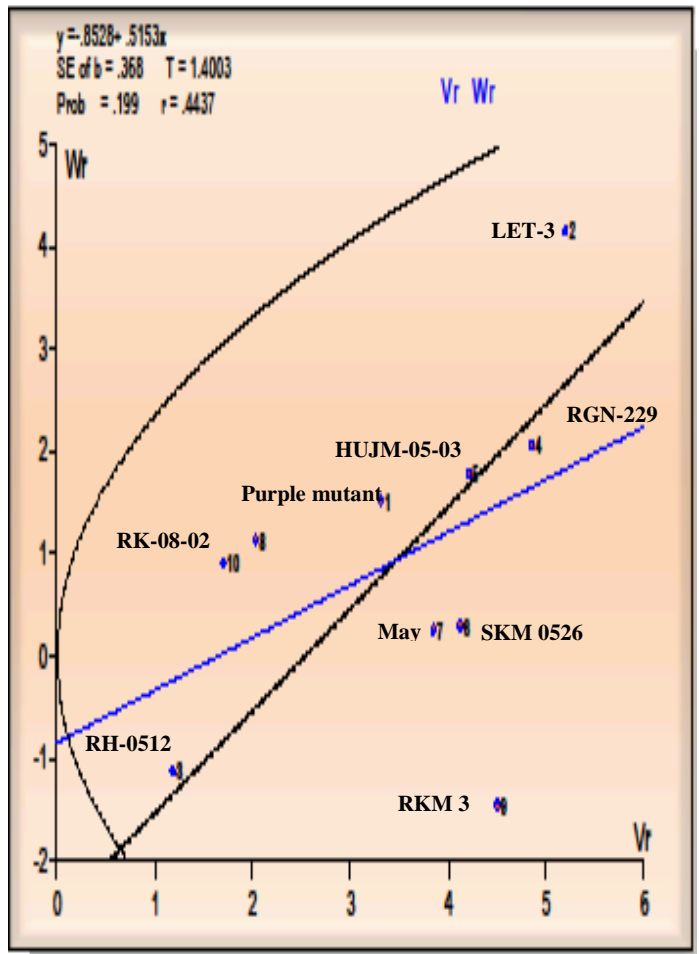

Fig.2 Vr/Wr graph for 1000 seed weight

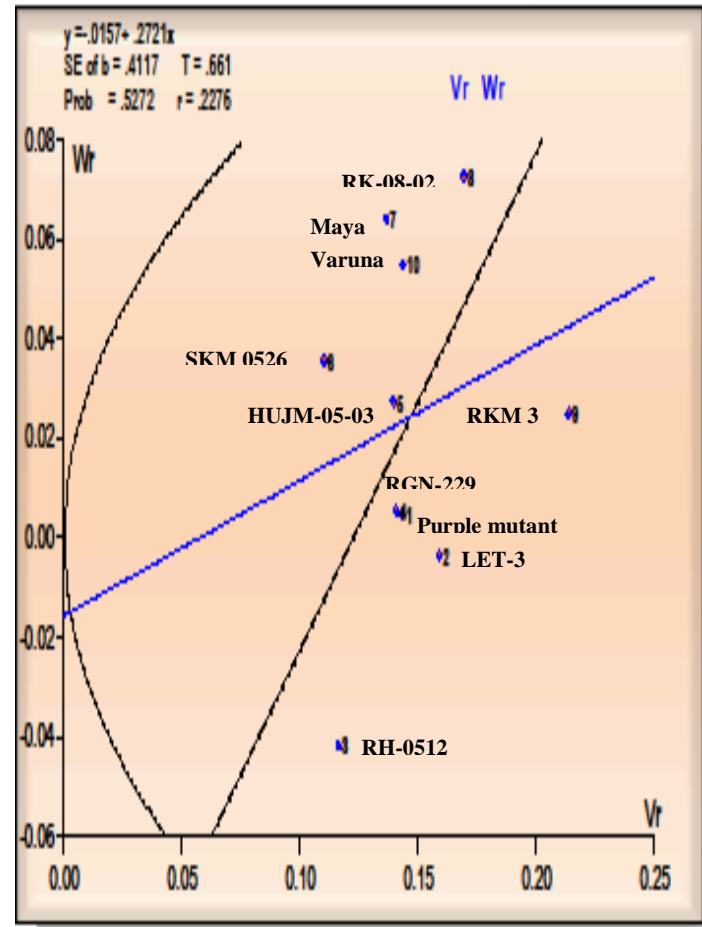


Fig.3 Vr/Wr. graph for seed yield/ plant

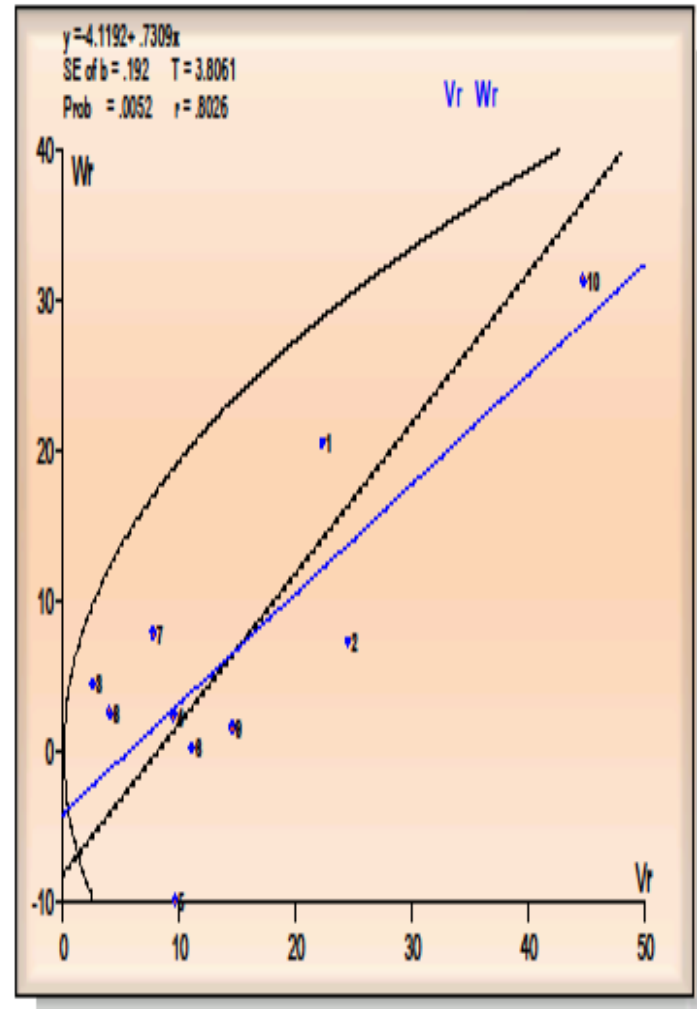

Fig.4 Vr/Wr graph for oil content

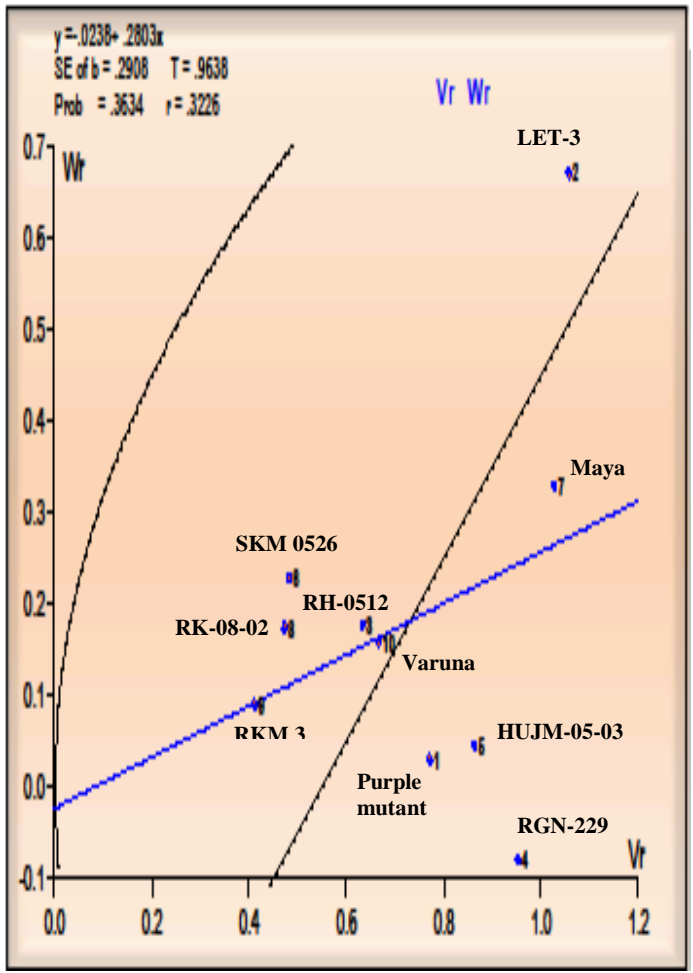


The inconsistency in the estimates of graphical and analytical method may be explained on the ground that the estimates obtained through the formulae of mean degree of dominance may not be appropriate for explaining the degree of dominance in real sense, since, particular combination of either positive or negative alleles or complementary type of gene action or simply correlated gene distribution may seriously inflate the mean degree of dominance and convert partial dominance into apparent over dominance (Hayman,1954). The analysis of the data reported in this study provided valuable information about the mechanisms of genetically controlled variation in some quantitative characters of Brassica plants. According to Mather and Jinks (1982) significant genotypic differences for the character may be manifested by additive genetic effects. However, to derive some useful and authentic information from the data, additive dominance model of Griffing (1956b), Hayman (1954a, b) and Jinks (1954) is a useful technique. Joint regression analysis of the data was carried out to test the validity of the data. The results of genetic analysis showed that four characters i.e. number of seeds per siliqua, 1000-seed weight, oil content and seed yield per plant were revealed to be predominantly influenced by the over dominant gene action (non-allelic interaction). Similar results have been reported by Nosin et. al. (2003), Ghosh and Gulati (2001), Larik and Rajput (2000) and Singh et al., (2000). Straight forward selection for particular character from the segregating population does not seem to be possible, the genetic variation existed in these characters could be improved successfully following reciprocal recurrent selection. Furthermore these characteristics with over dominance may advantageously to be utilized by the breeders in the development of hybrid, as suggested by Rao and Gulati (2001). However, before deriving some conclusive inferences, this information must be substantiated. The scatter of array points along the regression line for different characteristics suggested the existence of genetic diversity in the parental material meaning thereby that sufficient variation is present in the plant material which could be explored by following an appropriate breeding strategy. In view of the above discussion, it may be concluded that the plant traits involving over dominance type of gene action might be considered when heterosis is to be exploited in appropriate improvement programme.

\section{References}

Ghosh, S.K. and S.C. Gulati, 2001. Genetic variability and association of yield components in Indian mustard (Brassica juncea L.). Crop Res.Hisar, 21: 345-9

Hayman, B.I., 1954a. The theory of diallel crosses. Genetics, 39: 789-09

Hayman, B.I., 1954b. The analysis of variance of diallel tables. Biometrics, 10: 235-44

Jinks, J.L., 1954. Analysis of continuous variation in diallel crosses of Nicotiana rustica. Genetics, 39: 767-88

Kamala, T., 1999. Gene action for seed yield and yield components in sesame (Sesamum indicum). Indian J. Agric. Sci., 69: 773-4

Larik, A.S. and L.S. Rajput, 2000. Estimation of selection indices in Brassica juncea $L$. and Brassica napus L. Pakistan J. Bot., 32: $323-30$

Mather, K. and J.L. Jinks, 1982. Biometrical Genetics, 3rd Ed. Chapman and Hall, London

Rao, N.V.P.R.G. and S.C. Gulati, 2001. Comparison of gene action in F1 and F2 diallels of Indian mustard (Brassica juncea L. Czern and Coss). Crop Res. Hisar, 21: 72-6.

\section{How to cite this article:}

Ranjana, Ranjeet Singh, K. Kumar and Sharma, D.K. 2018. Inheritance Pattern of Quantitative Characters in Brassica juncea. Int.J.Curr.Microbiol.App.Sci. 7(07): 783-789. doi: https://doi.org/10.20546/ijcmas.2018.707.095 